\title{
A COMPARATIVE ANALYSIS OF THE INTENSIFIERS QUITE, RATHER, AND PRETTY USED BY AMERICANS AND BRITISH PEOPLE: A CORPUS-BASED STUDY
}

\author{
Rex Stardy* \\ English Language and Culture Department, Bunda Mulia University \\ Received on 5 April 2019 / Approved on 15 April 2019
}

\begin{abstract}
Words have many different meanings and this can cause problems for nonnative speakers of English. Because words can mean many different things depending on the sentence that they appear in, Indonesian learners of English often have trouble telling the different meanings apart, especially when the words are synonyms or from specific group of words like intensifiers. From this, the writer would like to do a research on the topic of the comparison between American and British English. The research is limited to comparing the intensifiers quite, rather and pretty. The data is taken from COCA for the American English and BNC for the British English. The result shows that in general, the three intensifiers are more or less similar in meaning, with only slight differences. The usages of these three intensifiers by Americans and British people are also not too different.
\end{abstract}

Keywords: intensifier, American and British people, corpus

\section{ABSTRAK}

Kata-kata memiliki banyak arti berbeda dan ini dapat menyebabkan masalah bagi penutur bahasa Inggris yang tidak asli. Karena kata-kata dapat berarti banyak hal yang berbeda tergantung pada kalimat yang muncul, para pelajar bahasa Inggris Indonesia sering mengalami kesulitan membedakan makna yang berbeda, terutama ketika kata-kata tersebut adalah sinonim atau dari kelompok kata tertentu seperti penguat. Dari sini, penulis ingin melakukan penelitian pada topik perbandingan antara bahasa Inggris yang digunakan oleh orang Amerika dan Inggris. Penelitian ini terbatas untuk membandingkan penguat quite, rather dan pretty. Data diambil dari COCA untuk Bahasa Inggris Amerika dan BNC untuk Bahasa Inggris orang Inggris. Hasilnya menunjukkan bahwa secara umum, ketiga penguat ini kurang lebih memiliki makna yang sama, dengan hanya sedikit perbedaan. Penggunaan ketiga penguat ini oleh orang Amerika dan Inggris juga tidak terlalu berbeda.

Kata Kunci: penguat, orang Amerika dan Inggris, korpus

\section{INTRODUCTION}

\subsection{Background}

Words in a language can have more than one meaning. For example, the word mouse in English can mean a small animal or a piece of technology that you can use for computers. The meaning of a word can change depending on the context of the sentence. Not only the meaning, but sometimes words can have different parts of speech too such as the word light. Light can be a noun which means an energy that allows us to see things, or it can also be an adjective which means the opposite of heavy. Even as an adjective, the word light can also have several meanings. For instance, besides the opposite of heavy, it can also mean a pale color. Because words can have many meanings, it is difficult for nonnative speakers of English to tell the difference between one meaning and another sometimes.

It is sometimes even harder for nonnative speakers of English to tell the

\footnotetext{
*Author(s) Correspondence:

E-mail: rexstardy@yahoo.com
} 
difference between words with similar meanings or words that are synonyms of one another. For example, the word big and large. Even though these two words are similar, it does not mean that we can use them in exactly the same way. For instance, if we look at the collocations of these two words, we can see that the word big can go with the word sister because it will mean 'older' sister. But we cannot exactly say large sister unless we really are talking about the size of the person. Another example is the collocation with the word problem. It is normal to say big problem, but it is not common to say large problem.

Besides having difficulty with words that are synonyms, nonnative speakers of English often have problems with certain groups of words such as intensifiers. Examples of intensifiers are words like really, very, so, truly, absolutely, completely, etc. Their function is more or less the same which is to make the meaning of other words stronger. However, just like the collocation of synonymous words, not all intensifiers can go together with every other word. An example is the adjective splendid. You can strengthen it using intensifiers like absolutely and truly, but you cannot combine it with words like very or completely.

Depending on who you talk to, nonnative speakers of English may also need to adjust their choice of words. For example, Americans and British people have different vocabulary for the same things like flat (British) and apartment (American). Not only different vocabulary, but Americans and British people use the same words differently too. An example is with the intensifiers quite, rather and pretty. As intensifiers, again their function is similar which is to strengthen or emphasize other words. However, the way that Americans and British people use them in sentences is somewhat different. How can we know this for sure? A good way of comparing between American and British English is to look at an American and British corpus. A well-known corpus of American English is COCA or Corpus of Contemporary American English, and a popular corpus for British
English is BNC or British National Corpus. By looking at these two corpora, we can try to find out the similarities and differences between American and British English.

\subsection{Statement of Problem and Research Questions}

The introduction above shows that words have many different meanings and this can cause problems for nonnative speakers of English. Of course, this includes Indonesians too since English is considered as a foreign language here. Because words can mean many different things depending on the sentence that they appear in, Indonesian learners of English often have trouble telling the different meanings apart, especially when the words are synonyms or from specific group of words like intensifiers. In addition, even the same words can be used differently between American and British English. In order to help us with this problem, we can try to look at two corpora from both varieties of English, which is COCA and $\mathrm{BNC}$.

Based on the background and problem above, the writer would like to do a research on the topic of the comparison between American and British English. The research is limited to comparing the intensifiers quite, rather and pretty. The reason for choosing these intensifiers is because these are common words but difficult to tell the difference between them, and they are sometimes used differently by Americans and British people. To find out the similar and different usages of these words, the writer is going to refer to COCA and BNC. The research questions for the research are:

1) What are the similarities and differences between the intensifiers quite, rather and pretty?

2) How do Americans and British people use these intensifiers?

\subsection{Objective of the Research}

The objective of the research is to explore the similarities and differences between 3 similar intensifiers and how the Americans and British people use them. We will be able to see whether these 3 words are

\footnotetext{
*Author(s) Correspondence:

E-mail: rexstardy@yahoo.com
} 
different from one another even though they seem similar at a glance. We will also be able to see whether the Americans and British people use them differently or not. In order to do this, we will refer to a corpus of American English, which is COCA, and a corpus of British English, which is BNC. The similarities and differences that are going to be explored are related to the frequency and the collocations of these words found in both COCA and BNC.

\subsection{Significance of the Research}

The significance of the study is that it will provide information about the similarities and differences between the intensifiers quite, rather and pretty. Since Indonesian learners of English often have problems with these kinds of words and how to use them appropriately, it is expected that the result of this study can help them have a better understanding of how to use them. Moreover, it can also tell them about how Americans and British people use these words. So in the end, the research is important because it can provide valuable information for the Indonesian learners of English and teach them how to use the intensifiers accurately and also how to tell the difference between how Americans and British people use them.

\section{THEORETICAL FRAMEWORK}

\subsection{Corpus}

Cheng (2012) defines corpus as "a collection of texts that has been compiled for a particular reason." Hunston (2002) also mentions that corpus is a collection of examples of natural language use. These two definitions tell us that a corpus is basically a collection of texts that consist of examples of how language is used naturally. There are many corpora which are available such as COCA, BNC, MICASE, CANCODE, etc. Because a corpus is compiled for a particular reason, the collection of texts is of course going to be different too. For example, COCA and $\mathrm{BNC}$ are examples of general corpus which consist of many different texts.
Different with MICASE and CANCODE which are specialized corpora and their collection of texts is smaller and more specific.

\subsection{Collocation}

Hunston (2002) gives a definition of collocation as "the tendency of words to be biased in the way they co-occur." In addition, McEnery, Xiao and Tono (2006) mention that collocation is "the characteristic co-occurrence patterns of words, i.e., which words typically co-occur in corpus data." Based on these two definitions, we can say that collocation refers to the common combination of words that normally go together and they can be found in corpus data. An example of collocation is the words take and bath. This is an example of a collocation because it is normal or common to say take a bath. In other words, these words go together naturally.

There are many types of collocations. One classification is given by Benson, Benson \& Ilson (1997). They divide collocations into grammatical and lexical collocation. Grammatical collocation is when the combination of words is between a dominant word and a preposition or other grammatical structures. For example, the words look into. This is a grammatical collocation because it combines the verb look and the preposition into. On the other hand, lexical collocation is the combination of dominant words such as verb + noun. So the words have dinner is an example of a lexical collocation because it combines the verb have and the noun dinner.

\subsection{Intensifiers}

Quirk et al. (1985, as cited in Athanasiadou, 2007) describe intensifiers as "adverbs that express extent or intensity." Moreover, Ito and Tagliamonte (2003) define intensifiers as "adverbs that maximize or boost meaning." From these two definitions it can be concluded that intensifiers are adverbs that modify the meaning of words by maximizing or boosting it. Some examples include words like absolutely, completely, very, really, etc. Since they are adverbs, they can be used to modify verbs and adjectives. For example, we can use the intensifier completely to modify

\footnotetext{
*Author(s) Correspondence:
}

E-mail: rexstardy@yahoo.com 
the verb defeat and we can also use it to modify the adjective absurd.

\subsection{Previous Studies}

Several researches on the topic of intensifiers have been done. For example, Ito and Tagliamonte (2003) did a research on the use of intensifiers by different groups of people. One of their findings is that the intensifier very is more commonly used by older speakers while really is more popular with the younger speakers. Another research by Romero (2012) compared the intensifiers in British and American English. Their findings show that there is a clear difference between how British and American people use certain intensifiers.

\section{RESEARCH METHODOLOGY}

\subsection{Data Source}

For this study, the data is taken from COCA for the American English and BNC for the British English. The data is limited to three intensifiers which are quite, rather and pretty. In order to limit the search in these two corpora, these words are limited to the part of speech of adverbs. For the collocations, they are also limited to adjective collocations only.

\subsection{Data Collection and Analysis}

To collect the data, the researcher refers to COCA and BNC. The researcher first inputs the three intensifiers into these corpora to find out the frequency of each word in each corpus. The frequency of each word is compared to see which group of people uses each word the most. The writer also looks at the concordance lines to try to find the differences between the usages of these intensifiers in American and British English. Besides looking at the concordance lines, the researcher also refers to the online Cambridge English Dictionary to find the meaning of these words. Finally, the writer looks at the collocations for each word which has been limited to adjective collocations only.

\section{FINDINGS AND DISCUSSION}

\subsection{Data Analysis}

First of all, before we look into how the intensifiers quite, rather and pretty are used in COCA and BNC, we should look at their definitions in the dictionary to see whether they are similar or different. The dictionary that is used for this research is the online Cambridge English Dictionary. This dictionary is used because it shows the definition for both American and British English. The definitions for the three intensifiers are as follow:

1) Quite

- British:

$>$ completely $=$ The two situations are quite different.

$>$ a little or a lot but not completely $=$ I'm quite tired but I can certainly walk a little further.

- American:

$>$ to a large degree $=$ School is quite different from what it once was.

$>$ completely $=$ I'm not quite done yet.

$>$ really or truly $=$ It was quite a remarkable speech.

\section{2) Rather}

- British:

$>$ quite, to a slight degree $=$ It's rather cold today, isn't it?

$>$ very, to a large degree $=$ Actually, I did rather well in my exams.

- American: -

\section{3) Pretty}

- British:

$>$ quite, but not extremely $=$ I'm pretty sure it was her.

- American:

$>$ to a large degree; to some degree $=$ She was pretty tired.

We can see from the definitions above that the three intensifiers are more or less the same or have the similar meanings. However, there are some slight differences; for example, the word

\footnotetext{
*Author(s) Correspondence:

E-mail: rexstardy@yahoo.com
} 
quite means 'completely' both in American and British English, but this meaning is not the same with the meaning of rather and pretty. But when comparing the American and British meaning for the word quite, it can be seen that the British meaning is 'a little' while the American meaning is 'to a large degree.' The American use of quite also has an additional meaning which is 'really or truly.' The word rather also does not have a meaning in the American English as an intensifier (or it is similar to the British meaning). Lastly, the
British and American definition for the word pretty is also somewhat different. For the British it means 'not extremely' but for the Americans it means 'to a large degree.'

\subsubsection{Frequency Comparison of Quite, Rather and Pretty}

To compare the three intensifiers, we are going to first look at the frequency of each word in COCA and BNC. The frequencies are as follow:

Figure 1. Frequency of Quite in COCA

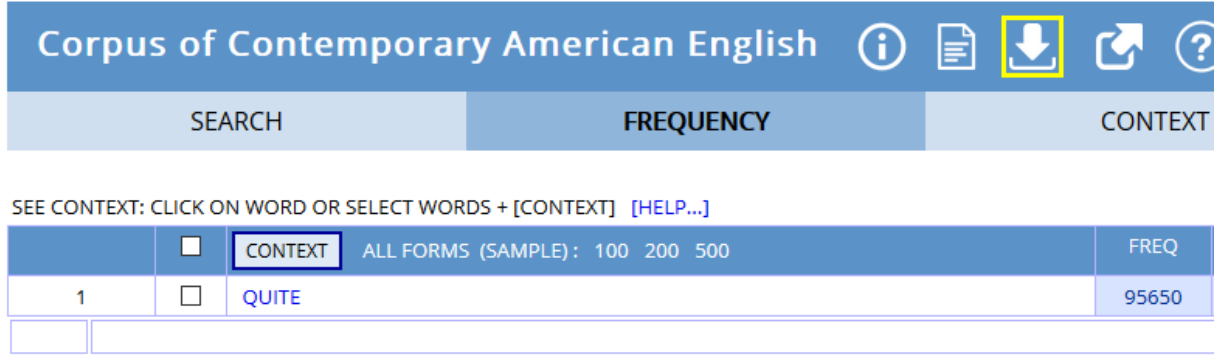

Figure 2. Frequency of Quite in BNC

$\begin{array}{ccc}\text { British National Corpus (BNC) (1) 国 ? ? } & \\ \text { SEARCH } & \text { CONTEXT }\end{array}$

SEE CONTEXT: CLICK ON WORD OR SELECT WORDS + [CONTEXT] [HELP...]
\begin{tabular}{|c|c|l|l|l|l|}
\hline \multicolumn{1}{|c|}{ CONTEXT } & ALL FORMS (SAMPLE) : $100 \quad 200 \quad 500$ & FREQ \\
\hline 1 & $\square$ & QUITE & & 39516 \\
\hline \hline
\end{tabular}

Figure 3. Frequency of Rather in COCA

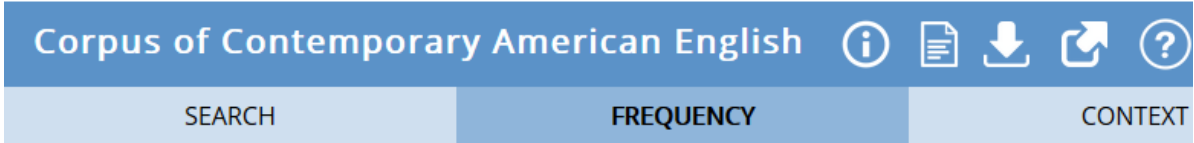

SEE CONTEXT: CLICK ON WORD OR SELECT WORDS + [CONTEXT] [HELP...]

\begin{tabular}{|c|c|l|l|l|}
\hline \multicolumn{1}{|c|}{} & $\square$ & CONTEXT & ALL FORMS (SAMPLE) : $100 \quad 200500$ & FREQ \\
\hline 1 & $\square$ & RATHER & 62123 \\
\hline \hline
\end{tabular}

*Author(s) Correspondence:

E-mail: rexstardy@yahoo.com 
Figure 4. Frequency of Rather in BNC

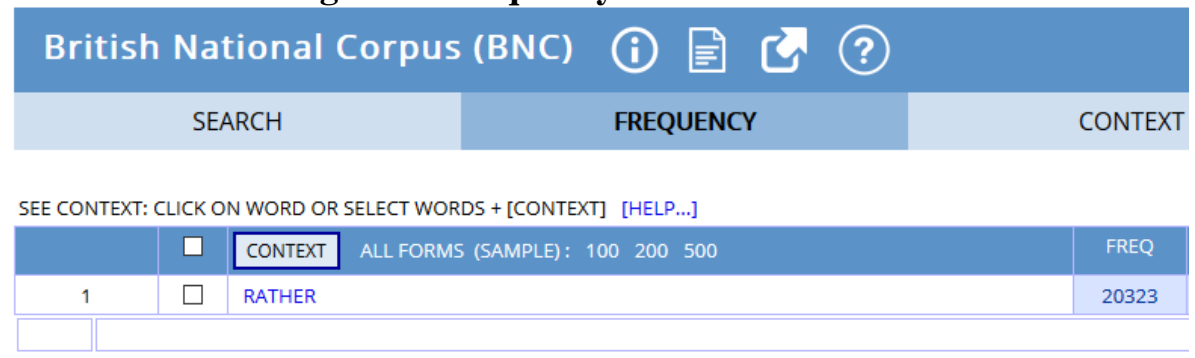

Figure 5. Frequency of Pretty in COCA

Corpus of Contemporary American English (i) 国 2 C 3 CONTEXT
SEARCH

SEE CONTEXT: CLICK ON WORD OR SELECT WORDS + [CONTEXT] [HELP...]
\begin{tabular}{|c|c|c|c|c|}
\hline \multicolumn{1}{|c|}{ CONTEXT } \\
\hline 1 & $\square$ & ALL FORMS (SAMPLE) : $100 \quad 200 \quad 500$ & FREQ \\
\hline \hline & $\square$ & PRETTY & 76856 \\
\hline
\end{tabular}

Figure 6. Frequency of Pretty in BNC

British National Corpus (BNC) (1) 国 \& ?
FEREQUENCY
CONTEXT

SEE CONTEXT: CLICK ON WORD OR SELECT WORDS + [CONTEXT] [HELP...]
\begin{tabular}{|c|c|l|l|l|l|}
\hline & $\square$ & CONTEXT \\
\hline 1 & $\square$ & PRETTY & ALL FORMS (SAMPLE): $100 \quad 200 \quad 500$ & FREQ \\
\hline \hline
\end{tabular}

As we can see from the figures above, the frequencies for each intensifier are quite different. Out of the three words, the one that is most frequently found in COCA and BNC is the word quite with a total of $\mathbf{9 5 , 6 5 0}$ occurrences in COCA and 39,516 occurrences in BNC. However, the least found in COCA is the word rather with 62,123 occurrences and the least found in $\mathrm{BNC}$ is the word pretty with only 4,750 occurrences. This shows that both Americans and British people often use the word quite as intensifiers in their utterances. Even though the difference in total is very large $(\mathbf{9 5 , 6 5 0}$ vs. 39,516), this is because we have to consider the size of the corpus. COCA consists of more than 560 million words while
BNC consists only of 100 million words. On the other hand, the Americans use rather the least while British people use pretty the least. This means that it is more common to use pretty as an intensifier for Americans, but it is more common to use rather as an intensifier for British people.

\subsubsection{Collocation Comparison of Quite, Rather and Pretty}

After looking at the frequency of the three words in COCA and BNC, we are now going to look into their collocations. The figures below show this:

*Author(s) Correspondence:

E-mail: rexstardy@yahoo.com 
Figure 7. Collocation of Quite in COCA

\begin{tabular}{|c|c|l|c|}
\hline & $\square$ & CONTEXT & FREQ \\
\hline 1 & $\square$ & DIFFERENT & 2698 \\
\hline 2 & $\square$ & SURE & 1765 \\
\hline 3 & $\square$ & CLEAR & 1026 \\
\hline 4 & $\square$ & GOOD & 736 \\
\hline 5 & $\square$ & RIGHT & 687 \\
\hline 6 & $\square$ & POSSIBLE & 575 \\
\hline 7 & $\square$ & READY & 426 \\
\hline 8 & $\square$ & SIMILAR & 414 \\
\hline 9 & $\square$ & SIMPLE & 351 \\
\hline 10 & $\square$ & SMALL & 349 \\
\hline
\end{tabular}

Figure 8. Collocation of Quite in BNC

\begin{tabular}{|c|c|l|c|}
\hline & $\square$ & CONTEXT & FREQ \\
\hline 1 & $\square$ & DIFFERENT & 1257 \\
\hline 2 & $\square$ & SURE & 717 \\
\hline 3 & $\square$ & GOOD & 585 \\
\hline 4 & $\square$ & CLEAR & 564 \\
\hline 5 & $\square$ & HAPPY & 559 \\
\hline 6 & $\square$ & RIGHT & 351 \\
\hline 7 & $\square$ & NICE & 314 \\
\hline 8 & $\square$ & POSSIBLE & 237 \\
\hline 9 & $\square$ & DIFFICULT & 207 \\
\hline 10 & $\square$ & EASY & 200 \\
\hline
\end{tabular}

From the figures above we can see that there are some similarities and differences of collocations for the intensifier quite in COCA and BNC. The words that are similar in both corpora are different, sure, clear, good, right, and possible. Even though the order is not exactly the same, these words are the top 10 most common collocations for the word quite in both COCA and BNC. However, the words ready, similar, simple and small are found in COCA but not in BNC, while the words happy, nice, difficult and easy are found in BNC but not in COCA.

Figure 9. Collocation of Rather in COCA

\begin{tabular}{|c|c|l|c|}
\hline & $\square$ & CONTEXT & FREQ \\
\hline 1 & $\square$ & LARGE & 326 \\
\hline 2 & $\square$ & DIFFERENT & 277 \\
\hline 3 & $\square$ & SMALL & 234 \\
\hline 4 & $\square$ & DIFFICULT & 155 \\
\hline 5 & $\square$ & LIKE & 144 \\
\hline 6 & $\square$ & UNUSUAL & 142 \\
\hline 7 & $\square$ & LIMITED & 122 \\
\hline 8 & $\square$ & GOOD & 117 \\
\hline 9 & $\square$ & SIMPLE & 110 \\
\hline 10 & $\square$ & LOW & 107 \\
\hline
\end{tabular}

*Author(s) Correspondence:

E-mail: rexstardy@yahoo.com 


\begin{tabular}{|c|l|l|l|}
\hline \multicolumn{3}{|c|}{ Figure 10. Collocation of Rather in BNC } \\
\cline { 2 - 4 } & $\square$ & CONTEXT \\
\hline 1 & $\square$ & DIFFERENT & 477 \\
\hline 2 & $\square$ & LIKE & 185 \\
\hline 3 & $\square$ & DIFFICULT & 110 \\
\hline 4 & $\square$ & GOOD & 96 \\
\hline 5 & $\square$ & NICE & 89 \\
\hline 6 & $\square$ & SMALL & 79 \\
\hline 7 & $\square$ & SIMILAR & 76 \\
\hline 8 & $\square$ & STRANGE & 72 \\
\hline 9 & $\square$ & ODD & 71 \\
\hline 10 & $\square$ & LARGE & 69 \\
\hline
\end{tabular}

Figure 9 and 10 above show us the collocations of the word rather in COCA and $\mathrm{BNC}$. We can see here that there are also some similarities and differences. The words large, different, small, difficult, like, and good are found in both corpora. But the words unusual, limited, simple and low are only found in COCA, while nice, similar, strange and odd are only found in BNC. So this means that Americans and British people sometimes use the intensifier rather differently. It should also be noted that the word like here is actually a verb and not an adjective, but it is somehow still included in the list even though the search has been limited to adjective collocations only.

Figure 11. Collocation of Pretty in COCA

\begin{tabular}{|c|c|l|c|}
\hline & \multicolumn{1}{|l|}{} & CONTEXT & FREQ \\
\hline 1 & $\square$ & GOOD & 10247 \\
\hline 2 & $\square$ & SURE & 2106 \\
\hline 3 & $\square$ & CLEAR & 1131 \\
\hline 4 & $\square$ & BAD & 1032 \\
\hline 5 & $\square$ & BIG & 936 \\
\hline 6 & $\square$ & COOL & 876 \\
\hline 7 & $\square$ & TOUGH & 662 \\
\hline 8 & $\square$ & CLOSE & 647 \\
\hline 9 & $\square$ & AMAZING & 609 \\
\hline 10 & $\square$ & HARD & 590 \\
\hline
\end{tabular}

Figure 12. Collocation of Pretty in BNC

\begin{tabular}{|c|c|l|c|}
\hline & $\square$ & CONTEXT & FREQ \\
\hline 1 & $\square$ & GOOD & 462 \\
\hline 2 & $\square$ & SURE & 157 \\
\hline 3 & $\square$ & WELL & 54 \\
\hline 4 & $\square$ & OBVIOUS & 52 \\
\hline 5 & $\square$ & BAD & 51 \\
\hline 6 & $\square$ & CERTAIN & 43 \\
\hline 7 & $\square$ & BIG & 40 \\
\hline 8 & $\square$ & CLEAR & 39 \\
\hline 9 & $\square$ & YOUNG & 39 \\
\hline 10 & $\square$ & CLOSE & 34 \\
\hline
\end{tabular}

*Author(s) Correspondence:

E-mail: rexstardy@yahoo.com 
From the figures above, we can see that similar to the previous words, there are some similar and different collocations for the word pretty in COCA and BNC. The similar words are good, sure, clear, bad, big, and close. The different words are cool, tough, amazing and hard which are found in COCA, and well, obvious, certain, and young which are found in BNC. It should also be noted that the frequency for the collocations in COCA are much higher compared to the collocations in BNC which shows that Americans like to use the word pretty as an intensifier compared to British people.

\subsubsection{Concordance Lines Comparison of Quite, Rather and Pretty}

We are now going to look into some concordance lines for each of the intensifiers to find out if they are similar to the dictionary definitions described at the beginning of the section.

\section{Figure 13. Concordance Lines of Quite in COCA}

raise. However, the cash flow streams from transmission line easements are quite peculiar. These easements are is one by Bottemiller and Wolverton (2013), who find generally quite small or nonexistent impacts on residential $\mathrm{F}$ niles, the function would tend to be quite steep and likely inappropriate for representing the magnitude of the effe here is that implicit prices for different land uses can be quite different. For example, the impact of transmission li

Figure 14. Concordance Lines of Quite in BNC

was kind to her in the summerhouse, though I'll assure you I was quite innocent then as now, and I desire you to keep : to sleep and not mind her. She'll come to bed when she's quite awake. PAMELA: Poor soul. BELVILLE gropes his way to favour and now with so much openness, affection and honour too, I am quite overcome. Presumption, you will say. So

If we look at the concordance lines above, the definition of quite in COCA is more about 'to a large degree' when combined with the words peculiar, small, steep and different. For example if the collocation is quite peculiar, it means that it is 'to a large degree' peculiar or strange, but it does not mean 'completely' or 'really or truly' peculiar. Whereas for the definition of quite in $\mathrm{BNC}$, it can be seen that it refers to the meaning of 'a little or a lot but not completely.' This can be seen when combined with the words innocent, awake and overcome. The collocation quite innocent means that the person is 'a little' innocent, but not 'completely' innocent.

Figure 15. Concordance Lines of Rather in COCA

eplaced from managing the fund during this period, as removal is rather difficult and expensive and usually only done as a last resort. juity, private real estate fee structures are not standardized, but rather complex. There is a wide variation of fee structures, even by st lagers will not outperform the market. The impact of this assumption is rather low given the number of funds using a relative benchm.

*Author(s) Correspondence:

E-mail: rexstardy@yahoo.com 
Figure 16. Concordance Lines of Rather in BNC

ep up our $\mathrm{R}$ and $\mathrm{D}$ efforts and had several rather successful new product introductions during the year. As a result with good control of the cost reduction is the accumulation of er of rather smaller ones, but the main ones are redundancy, sadly, more redundancy anc profits were down a little less than ten percent which is rather good going, given their (pause) erm heavy specialist skills in M and $\mathrm{Aw}$

Looking at the concordance lines above, we can see that the meaning of rather is similar to the dictionary one which is 'to a slight degree' in COCA. The words difficult, complex and low can be considered to be somewhat 'negative,' so when combined with these adjectives, the meaning of rather is more 'to a slight degree' or 'quite.' On the other hand, the concordance lines in BNC show that the meaning is probably more to 'very' or 'to a large degree.' This is because it is followed by 'positive' adjectives like successful and good. So the collocation rather good means 'very' good.

\section{Figure 17. Concordance Lines of Pretty in COCA}

igio or sauvignon blanc. To qualify " affordable, " consider that it is pretty easy to find a good Rueda verdejo that doesn't even venture into the en around. " \# What it all comes down to for Orchard is really pretty simple, though it's something he admitted is easier said than done: Sack esident have been talking about with regard to our economy. But the message was pretty clear. "\# Trump had blasted Murkowski in a tweet \&

Figure 18. Concordance Lines of Pretty in BNC

v kind words for their rivals.' Major and Lamont are doing a pretty good job of impersonating Stan and Ollie,' said Graham.' All league within a league.' Says Swales:' They fought pretty dirty. What concerns me is that a group of clubs had clandestine me when asked about her future she said:' Next year? It's pretty hard to think about that when you've just gone out of a Grand Sli

Lastly, if we look at the concordance lines above, it can be said that the definitions of pretty as an adverb are also similar to the dictionary meanings. For example, the word pretty is combined with easy, simple and clear in COCA, which shows that the meaning is 'to a large degree.' So the collocation pretty easy means that it is 'to a large degree' or 'very' easy. Similarly, the concordance lines in BNC show that the meaning is 'quite, but not extremely' because the word pretty is combined with dirty and hard. So the collocation pretty hard means that it is 'quite' hard but not 'extremely' hard.

\subsection{Discussion}

After we have seen the data analysis, we are now going to discuss the findings for this research and answer the research questions. The first is about the similarities and differences of the three intensifiers. First of all, they are more or less similar in terms of meaning according to the dictionary. All of them talk about a certain degree, whether it is slight or large degree. The only difference is in the word quite, where there is the meaning of 'completely.' Lastly, if we look at the collocations for the three intensifiers, we can see that they all share one similar adjective between them which is the word good. In other words, the adjective good can be modified using either quite, rather or pretty. Beside that word, there are some other similar adjectives that they share, but not between all three words. For example, the word different is a common collocation for quite and rather but not for pretty. In other words, if we compare all three intensifiers, they each have their own common collocations and are not all exactly the same.

\footnotetext{
*Author(s) Correspondence:
}

E-mail: rexstardy@yahoo.com 
The second research question is about how the Americans and British people use these three intensifiers. First of all, in terms of frequency, both groups used the word quite the most. So, it can be said that this word is a common intensifier for both Americans and British people. However, the difference is in the word that is used the least. The Americans use rather the least while the British people use pretty the least. This shows that each group has a certain preference over some intensifiers. The Americans do not like to use rather while the British people do not like to use pretty as intensifiers. Especially for the British people, where according to $\mathrm{BNC}$, only use the word pretty $\mathbf{4 , 7 5 0}$ times as an intensifier, which is quite a small number compared to the other two intensifiers (quite $=$ 39,516 and rather $=20,323$ ).

Next, about the collocations for the three intensifiers, some are similar but others are different between the Americans and British people. For example, the adjectives different, sure and clear are collocations of the word quite for both Americans and British people. However, words like simple and small are only used by Americans while happy and nice are only used by British people. So, it can be said that between the two groups of people, they sometimes use the intensifiers with similar adjectives, but at other times use them with different ones.

Finally, when we look at the concordance lines, we can see that there are some differences between how the Americans and British people use the intensifiers in terms of their meaning. For example for the word quite, the meaning for the Americans is 'to a large degree' while the meaning for the British people is 'a little but not completely.' Even though both of them refer to the meaning talking about 'degree,' the difference is whether it is a large or slight degree. This also depends on the adjective that follows the intensifier. If it is followed by words like peculiar, the word quite means 'very.' But when it is followed by words like innocent, it means 'a little.'

\footnotetext{
*Author(s) Correspondence:

E-mail: rexstardy@yahoo.com
}

\section{CONCLUSION AND SUGGESTIONS}

\subsection{Conclusion}

Based on the description above, it can be concluded that in general, the three intensifiers quite, rather and pretty are more or less similar in meaning, with only slight differences. In other words, it is true that they are synonyms because their meaning is really quite similar with one another. As for their collocations, they only share one adjective which is the same, which is the word good. Other than that, the three words have some similar collocations, but not for all three words. So some collocations are similar for quite and rather, but different for pretty. Or some are similar for rather and pretty, but different for quite.

As for the usages of these three intensifiers by Americans and British people, it could be said that overall they are not too different. Some intensifiers are preferred by a certain group, for example Americans like to use pretty while British people do not. However, in general the way they use them is not too different. For instance, both groups of people share similar collocations for these three intensifiers. Their meanings are also somewhat the same which is talking about a degree, although sometimes between the Americans and British people there are some differences in terms of small or large degree.

\subsection{Suggestions}

From the result of this research, there are two suggestions that we can make. First of all, since the result show that the difference between the three intensifiers is not too significant, it means that we can use them in more or less the same way. In other words, teachers can teach these intensifiers similarly and language users can also use them in more or less the same way. Also, between Americans and British people, the differences in the usages is also not that much. Finally, since this research is limited in terms of the number of intensifiers, it can be suggested that researchers explore different words other than these three words. They can also try to 
compare the usages of intensifiers not only by American and British people, but also by other groups of people.

\section{REFERENCES}

Athanasiadou, A. (2007). On the subjectivity of intensifiers. Language Sciences, 29, 554-565.

Benson, M., Benson, E., \& Ilson, R. (1997). The BBI dictionary of English word combinations (Revised Edition). Amsterdam: John Benjamins Publishing Company.

British National Corpus. https://www.englishcorpora.org/bnc/

Cambridge English Dictionary. https://dictionary.cambridge.org/

Cheng, W. (2012). Exploring corpus linguistics: language in action. New York: Routledge.
Corpus of Contemporary American English. http://corpus.byu.edu/coca/

Hunston, S. (2002). Corpora in applied linguistics. Cambridge: Cambridge University Press.

Ito, R \& Tagliamonte, S. (2003). Well weird, right dodgy, very strange, really cool: layering and recycling in English intensifiers. Language in society, 32, 257-279.

McEnery, T., Xiao, R., \& Tono, Y. (2006). Corpus-based language studies: an advanced resource book. New York: Routledge.

Romero, S. (2012). This is so cool! - a comparative corpus study on intensifiers in British and American English. Unpublished Research. Tampere: University of Tampere.

*Author(s) Correspondence:

E-mail: rexstardy@yahoo.com 